\title{
Heterogeneity of familial porphyria cutanea tarda
}

\author{
ANDREW G ROBERTS*, GEORGE H ELDER*, \\ ROBERT G NEWCOMBE†, RAFAEL ENRIQUEZ DE SALAMANCA , \\ AND JUAN J MUNOZ \\ From the Departments of Medical Biochemistry* and Medical Computing and Statisticst, University of Wales \\ College of Medicine, Cardiff CF4 4XN; and ¥the Department of Internal Medicine, Hospital Clinico de San \\ Carlos, Madrid, Spain.
}

SUMMARY The concentration of immunoreactive uroporphyrinogen decarboxylase has been measured in erythrocytes from 17 patients with porphyria cutanea tarda (PCT) from 10 families, from 74 of their relatives, and from 47 control subjects. The 10 families were divided into two groups according to their erythrocyte enzyme concentrations. Group A contained four families in which at least two subjects had overt PCT. All members of these families, including seven patients with overt PCT, had normal erythrocyte uroporphyrinogen decarboxylase concentrations and activities. Apart from their family history, patients in group A were clinically and biochemically indistinguishable from cases of type I (sporadic) PCT. Group B contained six families with the only previously described form of familial PCT (type II PCT) in which decreased erythrocyte uroporphyrinogen decarboxylase segregates as an autosomal dominant trait. These findings show that familial PCT is heterogeneous and suggest that inheritance contributes to the pathogenesis of at least some cases of type I PCT.

Porphyria cutanea tarda (PCT), the commonest cutaneous porphyria, is a syndrome in which the characteristic skin lesions of the hepatic porphyrias are associated with a specific pattern of porphyrin overproduction. ${ }^{1}$ Most cases of PCT appeared to be precipitated by liver cell damage, usually caused by alcohol or by oestrogens. ${ }^{1}$ Because PCT is an uncommon complication of widespread conditions such as alcoholism, Waldenstrom and HaegerAronsen ${ }^{2}$ suggested that patients have an inherited predisposition to the disorder, a hypothesis that was supported by the occasional occurrence of overt PCT in families. ${ }^{3}$

The clinical and metabolic abnormalities of PCT are caused by decreased activity of uroporphyrinogen decarboxylase (EC 4.1.1.37) in the liver. ${ }^{4}{ }^{5}$ Two causes of this enzyme defect have been identified: poisoning by polyhalogenated aromatic hydrocarbons such as hexachlorobenzene ${ }^{6}$ and autosomal dominant inheritance of a uroporphyrinogen decarboxylase deficiency that is present in all tissues, including erythrocytes. ${ }^{47}$ The first of these is rare while the second, type II or familial PCT, probably explains no more than $25 \%$ of cases. Thus, the cause of the hepatic enzyme defect in the majority of

Received for publication 20 May 1987.

Accepted for publication 29 September 1987. patients with PCT remains unexplained. These patients, classified as type I or sporadic PCT, have normal erythrocyte uroporphyrinogen decarboxylase concentrations and activities, no relatives with the condition, and no history of exposure to known porphyrogenic chemicals. In particular, the case for an inherited predisposition in this group has been weakened by the demonstration that virtually all patients with a family history of PCT have the type II disorder, ${ }^{4-11}$ the only possible exceptions being two Spanish families. ${ }^{11}$

We now describe a comparison of four Spanish families, including the two reported previously, ${ }^{11}$ with six type II PCT families that shows the existence of a second form of familial PCT in which individual patients, apart from their family history, are indistinguishable from those with the type I form.

\section{Patients and methods}

PATIENTS AND CONTROL SUBJECTS

During a study of patients with PCT who gave a history at presentation of at least one affected relative, four unrelated patients were identified who had erythrocyte uroporphyrinogen decarboxylase activities and concentrations well within the range for normal subjects. Clinical and biochemical data 
TABLE 1 Patients with PCT (group A, families 1 to 4).

\begin{tabular}{|c|c|c|c|c|c|c|c|c|c|}
\hline \multirow[t]{2}{*}{ Family } & \multirow[t]{2}{*}{ Patient } & \multirow{2}{*}{$\begin{array}{l}\text { Age at } \\
\text { onset }\end{array}$} & \multirow{2}{*}{$\begin{array}{l}\text { Precipitating } \\
\text { factors }\end{array}$} & \multicolumn{3}{|c|}{ Urinary porphyrin } & \multirow{2}{*}{$\begin{array}{l}\begin{array}{l}\text { Faecal } \\
\text { porphyrin }\end{array} \\
\text { Isocopro/copro }\end{array}$} & \multirow{2}{*}{$\begin{array}{l}\text { Liver } \\
\text { porphyrin }\end{array}$} & \multirow{2}{*}{$\begin{array}{l}\text { Liver } \\
\text { pathology }\end{array}$} \\
\hline & & & & $\begin{array}{l}\text { Total } \\
(\mu \mathrm{g} / \mathrm{l})\end{array}$ & $\begin{array}{l}\text { Uro } \\
(\%)\end{array}$ & $\begin{array}{l}\text { Hepta } \\
(\%)\end{array}$ & & & \\
\hline 1 & I. 3 & 64 & Alc $>120 \mathrm{~g} / \mathrm{d}$ & 1066 & 55 & 35 & $2 \cdot 2$ & & \\
\hline 1 & II. 2 & 38 & Alc $>150 \mathrm{~g} / \mathrm{d}$ & 3866 & 48 & 32 & $2 \cdot 5$ & + & Chronic persistent hepatitis \\
\hline 2 & II. 1 & 63 & $\mathrm{O}$ & 422 & 66 & 27 & 0.9 & & \\
\hline 2 & II. 3 & 52 & Alc $50 \mathrm{~g} / \mathrm{d}$ & 1600 & 58 & 38 & $2 \cdot 6$ & & \\
\hline 2 & II $\cdot 11$ & 41 & Alc $70 \mathrm{~g} / \mathrm{d}$ & 1496 & 32 & 40 & $2 \cdot 4$ & & \\
\hline 3 & I.4 & 55 & Alc $>60 \mathrm{~g} / \mathrm{d}$ & 4522 & 67 & 28 & $1 \cdot 5$ & + & $\begin{array}{l}\text { Chronic persistent hepatitis, } \\
\text { mild siderosis }\end{array}$ \\
\hline 3 & I.5 & 59 & ?Alc & 290 & 33 & 29 & 0.52 & + & $\begin{array}{r}\text { Chronic active hepatitis: } 1^{\circ} \\
\text { hepatocellular carcinoma }\end{array}$ \\
\hline 4 & I. 2 & 63 & Alc $>80 \mathrm{~g} / \mathrm{d}$ & 655 & 42 & 31 & $1 \cdot 8$ & & \\
\hline 4 & II. 2 & 31 & Alc $50 \mathrm{~g} / \mathrm{d}$ & 1214 & 47 & 37 & $2 \cdot 2$ & & $\begin{array}{l}\text { "Non-specific changes, mild } \\
\text { siderosis }\end{array}$ \\
\hline \multicolumn{4}{|c|}{ Reference ranges: } & $0-110$ & & & $<0.05$ & & \\
\hline
\end{tabular}

${ }^{*}$ Liver porphyrin not measured during active phase (see text). Alc: estimated alcohol intake; O: no precipitating factors (alcohol, oestrogen, porphyrogenic chemicals) identified. Isocopro/copro:isocoproporphyrin/coproporphyrin ratio.
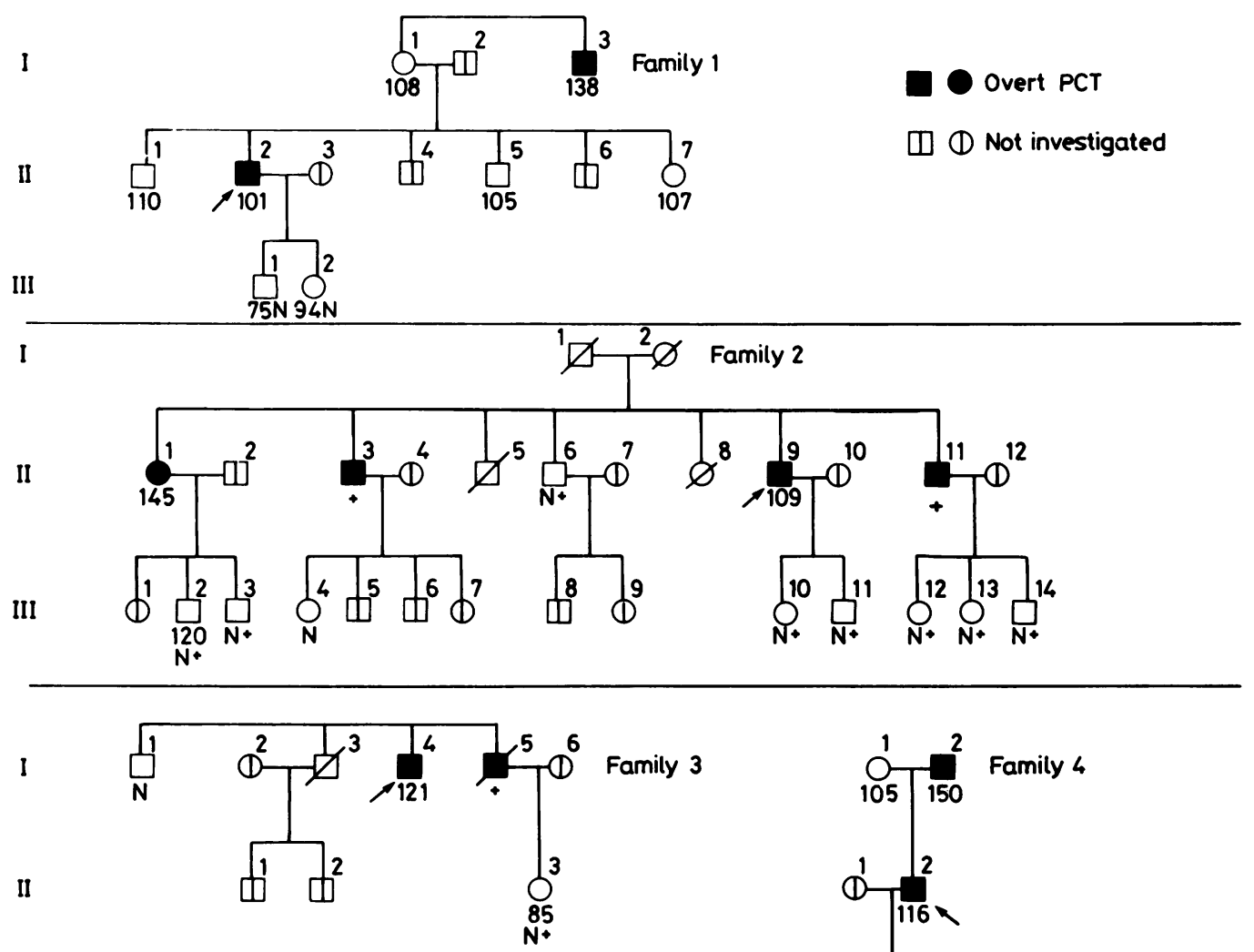

III

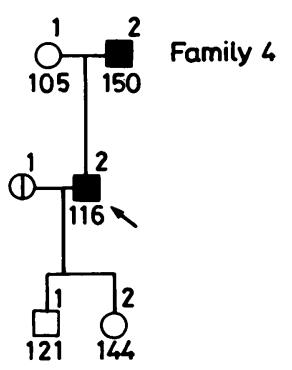

FIG 1 Families 1 to 4 (group A families). Figures below symbols are erythrocyte uroporphyrinogen decarboxylase concentrations in $n g \cdot m g^{-1}$. N: subjects with normal urinary porphyrin excretion; urine from other asymptomatic subjects was not examined, +: subjects with normal erythrocyte uroporphyrinogen decarboxylase activity (see reference 11: families E and $F$.) 
for all patients with overt PCT from these families (group A, families 1 to 4 ) are given in table 1 . All were haematologically normal. Erythrocyte uroporphyrinogen decarboxylase and urinary and faecal porphyrin excretion were measured in all available first degree relatives of these patients. Clinical features of family 2 have been reported. ${ }^{12}$

Erythrocyte uroporphyrinogen decarboxylase was also measured in all available members of six families with type II PCT (group B, families 5 to 10) (10 affected subjects, 38 first degree, and 26 second degree relatives). For each family, the diagnosis of type II PCT was established by showing increased excretion of uroporphyrin and heptacarboxylic porphyrin in urine and isocoproporphyrin in faeces in all affected subjects, together with decreased erythrocyte uroporphyrinogen decarboxylase in the proband and at least one first degree relative. Two families were from the United Kingdom, two from Spain, and one each from Australia and the United States. Porphyrin excretion was measured in all members of the Spanish families. Control subjects were unrelated and had no clinical evidence or family history of porphyria.

\section{LABORATORY METHODS}

Whole blood for measurement of immunoreactive and catalytic uroporphyrinogen decarboxylase was anticoagulated with EDTA and stored at $-70^{\circ} \mathrm{C}$ until analysis. Biopsy samples of skin were obtained from the upper arm for culture of fibroblasts by standard procedures. Needle biopsy samples of liver were frozen at $-70^{\circ} \mathrm{C}$ as soon as obtained and stored at this temperature. Liver and fibroblasts were homogenised in $50 \mathrm{mmol} / \mathrm{l} \mathrm{K}$-phosphate buffer, $\mathrm{pH}$ $6 \cdot 8$, and centrifuged at $25000 g_{\text {av }}$ for five minutes. Aliquots of the supernatant fraction were taken for assay of uroporphyrinogen decarboxylase. Uroporphyrinogen decarboxylase activity was measured as described by Elder and Wyvill ${ }^{13}$ using pentacarboxyl porphyrinogen III or uroporphyrinogen III as substrate. Immunoreactive uroporphyrinogen decar- boxylase was measured by a radiochemical electroimmunoassay ${ }^{5}$ with a between batch coefficient of variation of $10 \cdot 5 \%$. Porphyrin excretion was measured as described by Enriquez de Salamanca $e t$ $a l .{ }^{14}$

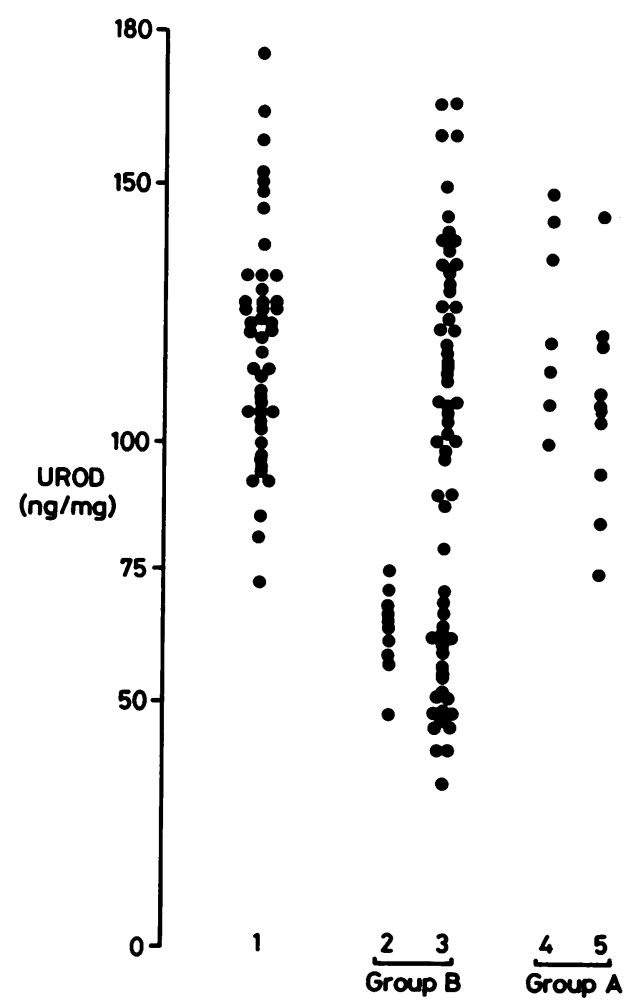

FIG 2 Erythrocyte uroporphyrinogen decarboxylase concentrations. Erythrocyte uroporphyrinogen decarboxylase (UROD) concentrations are shown for control subjects (1), for patients from families 5 to 10 (group $B$ patients) with type II PCT. (2) and their asymptomatic relatives (3), and for patients from families 1 to 4 (group $A$ patients) (4) and their asymptomatic relatives (5).

TABLE 2 Families 1 to 4: uroporphyrinogen decarboxylase in patients with PCT.

\begin{tabular}{|c|c|c|c|c|c|}
\hline Group & No & Tissue & $\begin{array}{l}\text { Catalytic activity } \\
\text { (pmol/min/mg) }\end{array}$ & $\begin{array}{l}\text { Concentration } \\
\text { (ng/mg) }\end{array}$ & $\begin{array}{l}\text { Specific activity } \\
\text { (nmol/min/mg) }\end{array}$ \\
\hline PCT & 7 & Erythrocytes & $\begin{array}{l}21 \cdot 7 \\
(17 \cdot 1-24 \cdot 2)\end{array}$ & $\begin{array}{l}125 \\
(88-147)\end{array}$ & $\begin{array}{l}0.18 \\
(0.16-0.20)\end{array}$ \\
\hline Controls & 8 & Erythrocytes & $\begin{array}{l}21 \cdot 8 \\
(19 \cdot 3-24 \cdot 3)\end{array}$ & $\begin{array}{l}129 \\
(101-151)\end{array}$ & $\begin{array}{l}0.17 \\
(0.14-0.20)\end{array}$ \\
\hline PCT (2 II.9) & 1 & Fibroblasts & $19 \cdot 6$ & 333 & 0.06 \\
\hline Controls & 3 & Fibroblasts & $\begin{array}{l}22 \cdot 8 \\
(17 \cdot 1-27 \cdot 4)\end{array}$ & $\begin{array}{l}373 \\
(346-409)\end{array}$ & $\begin{array}{l}0.06 \\
(0.05-0.07)\end{array}$ \\
\hline PCT (4 II.2) & 1 & Liver & $14 \cdot 8 \pm 2 \cdot 7$ & 127 & 0.12 \\
\hline Controls & 16 & Liver & $\begin{array}{l}12 \cdot 8 \\
(9 \cdot 1-18 \cdot 2)\end{array}$ & $\begin{array}{l}124 \\
(86-172)\end{array}$ & $\begin{array}{l}0.10 \\
(0.07-0.15)\end{array}$ \\
\hline
\end{tabular}

Figures are means and ranges of values for separate subjects or, for catalytic activity in liver, the mean and range for duplicate measures. Erythrocyte activities and concentrations are per $\mathrm{mg}$ of haemoglobin, the other measurements are per $\mathrm{mg}$ protein. 
STATISTICAL METHODS

Statistical procedures are described in the appendix.

\section{Results}

The families of the four patients (group A) who had both a family history of overt PCT and normal erythrocyte uroporphyrinogen decarboxylase concentrations and activities are shown in fig 1 . Erythrocyte enzyme measurements for the four probands and three other patients (family 1, I.3; family 2, II.1; family 4, I.2) from these families were well within the ranges for control subjects (table 2) whether pentacarboxyl porphyrinogen III or uroporphyrinogen III were used as substrates to determine catalytic activity. Catalytic activity and the concentration of immunoreactive enzyme was also normal in fibroblasts from one patient (family 2 , II.9) and in liver from another patient (family 1 , II.2), who had been in remission for four and a half years and had a normal hepatic porphyrin concentration. Although the kinetic properties of erythrocyte uroporphyrinogen decarboxylase from these patients were not investigated in detail, no major differences were found between the $\mathrm{K}_{\mathrm{m}}$ and $\mathrm{V}_{\max }$ values for pentacarboxyl porphyrinogen III for three of the probands $\left(\mathrm{K}_{\mathrm{m}}: 2.4\right.$ to 3.4 , mean $3.0 \mu \mathrm{mol} / \mathrm{l}$; $\mathrm{V}_{\text {max }}: 22.7$ to 32.8 , mean $26.2 \mathrm{pmol} / \mathrm{min} / \mathrm{mg}$ ) and three control subjects $\left(K_{m}: 2.4\right.$ to $4 \cdot 0$, mean 3.0 $\mu \mathrm{mol} / \mathrm{l} ; \mathrm{V}_{\text {max }}: 20 \cdot 3$ to $28 \cdot 6$, mean $24 \cdot 3 \mathrm{pmol} / \mathrm{min} / \mathrm{mg}$ ). Urinary porphyrin excretion was normal in the 12 first degree relatives that were investigated (fig 1).

Fig 2 compares the frequency distributions of the erythrocyte enzyme concentrations in group $\mathrm{A}$,
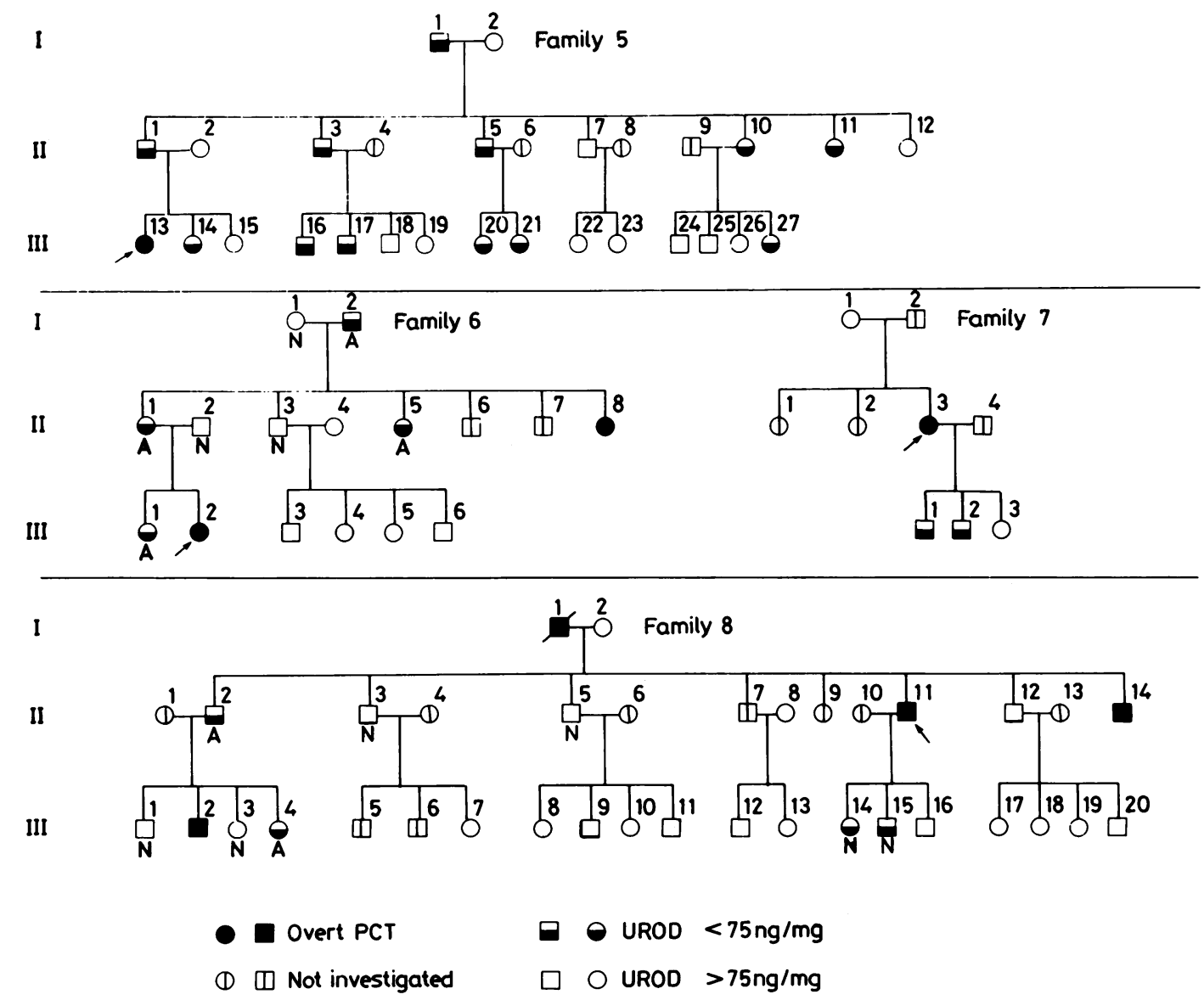

FIG 3 Families with type II PCT (group B families). UROD: erythrocyte uroporphyrinogen decarboxylase; N: subjects with normal porphyrin excretion; A: asymptomatic subjects with abnormal porphyrin excretion (subclinical PCT). Urinary porphyrin excretion was not measured in asymptomatic subjects without a subscript letter. 
group B (type II PCT), and control subjects. The pedigrees of the four largest group B (type II PCT) families are shown in fig 3 . The differences between the two groups of families are striking (figs 1 to 3): there is a clear bimodal distribution and autosomal dominant pattern of segregation of low enzyme concentrations (less than $75 \mathrm{ng} \cdot \mathrm{mg}$ haemoglobin ${ }^{-1}$ ) in the group B families, while concentrations for the 17 subjects from the group $A$ families are all within the control range. Investigation of urinary porphyrin excretion in families 5 and 8 from group B showed that six of 15 asymptomatic first degree relatives had abnormalities typical of subclinical PCT (fig 3).

Because there is often some overlap between the ranges for control and affected persons when enzyme measurements in peripheral cells are used to detect absence of expression of one of a pair of allelic genes, we used a number of statistical methods to examine the possibility that the difference between the two groups of families might have arisen by chance. The results summarised in the appendix and table 4 show that the difference is

TABLE 3 Log erythrocyte uroporphyrinogen decarboxylase concentration by family group and phenotype.

\begin{tabular}{lcll}
\hline Families & \multicolumn{3}{l}{ Log UROD concentration } \\
\cline { 2 - 4 } & No & Mean & SD \\
\hline Families 1 to 4 & 7 & 2.095 & 0.065 \\
Overt PCT & 10 & 2.022 & 0.081 \\
Asymptomatic & & & \\
Families 5 to 10 & 10 & 1.799 & 0.060 \\
Overt PCT & 24 & 1.735 & 0.085 \\
Asymptomatic UROD <75 ng/mg & 40 & 2.080 & 0.078 \\
Control subjects & 47 & 2.072 & 0.081 \\
\hline
\end{tabular}

For families 5 to 10 , the pattern in clinically unaffected subjects is bimodal with two subgroups separating at an erythrocyte uroporphyrinogen decarboxylase (UROD) concentration of approximately $75 \mathrm{ng} / \mathrm{mg}$. highly significant even by very conservative testing procedures.

\section{Discussion}

This study shows that patients with PCT who have relatives with the disorder do not invariably have the autosomal dominantly inherited deficiency of erythrocyte uroporphyrinogen decarboxylase that defines type II PCT. Apart from having at least one close relative with PCT, the 10 group A patients (families 1 to 4) (table 1) are clinically and biochemically indistinguishable from those with the sporadic or type I form of PCT. None presented at the early age (less than 20 years) that is sometimes a feature of type II PCT and that constitutes the only reliable clinical means of distinguishing the two types. ${ }^{71} \mathrm{In}$ addition, uroporphyrinogen decarboxylase activities and concentrations were normal in erythrocytes, fibroblasts, and, after prolonged remission, in liver: all features of type I PCT. ${ }^{5}$ Unfortunately, it was not possible to measure uroporphyrinogen decarboxylase in liver from any patient during the clinically active stage, but biopsy samples obtained at this time did show marked increases in porphyrin content (table 1) indicating that enzyme activity was likely to be decreased. ${ }^{5}$

The pedigrees in fig 1 show aggregation of overt PCT within families in a pattern that could be produced either by genetic or environmental factors acting separately or together. Clustering due to common contact with a toxic compound seems unlikely to be the sole explanation. There was no evidence of exposure to toxic amounts of any of the chemicals that are known to decrease hepatic uroporphyrinogen decarboxylase activity in $\operatorname{man}^{6}$ and adult patients from the same family were often geographically and socially separate. A more likely explanation is that the predisposition to develop

TABLE 4 Summary of significance tests for difference between families 1 to 4 and 5 to 10.

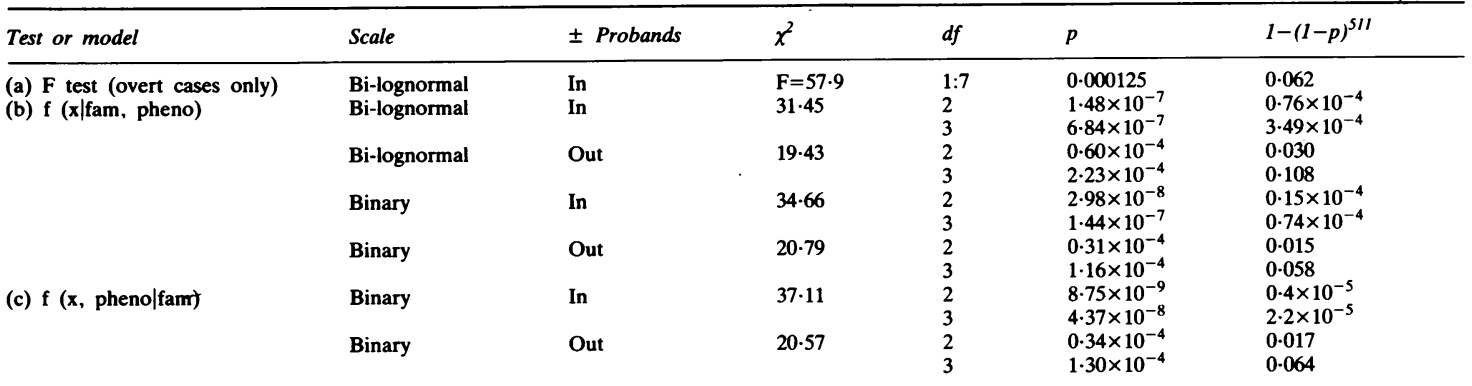

See appendix for explanation of statistical methods. 
PCT is inherited in these families either as an autosomal dominant trait with incomplete penetrance or as an autosomal recessive characteristic. For the latter, it is necessary to postulate that families 1 and 4 (fig 1) result from homozygoteheterozygote marriages, which, in the absence of any evidence of consanguinity, would suggest that the gene is not uncommon in the population. Since overt PCT normally develops only in response to acquired factors, many of those homozygous for this gene might be expected to remain asymptomatic throughout life. ${ }^{15}$

Identification of these group A families has three main implications for study of the pathogenesis of PCT. First, do they demonstrate the existence of a mutation at the uroporphyrinogen decarboxylase locus that selectively decreases activity of the enzyme in liver? An inherited variant of acute intermittent porphyria in which erythrocyte porphobilinogen deaminase activity is normal has been described ${ }^{16}$ and recent evidence that the single gene for this enzyme gives rise to specific erythroid and nonerythroid isoenzymes ${ }^{17}$ suggests a molecular explanation for a liver specific mutation in this variant. However, there is evidence against a similar explanation for the form of PCT described here. Human uroporphyrinogen decarboxylase is encoded by a single gene on the short arm of chromosome $1^{18}$ and sequencing of cDNAs for mRNAs from erythroid and non-erythroid tissues has shown no significant sequence differences, ${ }^{19}{ }^{20}$ consistent with a report that erythroid and hepatic enzymes are immunochemically and catalytically indistinguishable. ${ }^{21}$ Although mutation at a site that regulates tissue specific expression is not excluded by this evidence, such an explanation seems unlikely in view of our finding that the concentration and activity of hepatic uroporphyrinogen decarboxylase was normal in one patient after prolonged remission (table 2). However, a mutation that alters the amino acid sequence of the enzyme so as to make it susceptible to an inactivation process that operates only in the liver ${ }^{22}$ would not have been detected by our erythrocyte measurements and remains a possible explanation.

Second, do our results provide evidence for a mutation at some other locus that predisposes people to develop PCT in response to acquired factors such as alcohol and hepatic siderosis? The development of an analogous experimental porphyria in mice is influenced by inheritance of inducibility of certain cytochrome $\mathrm{P} 450$ mediated reactions. ${ }^{6}$ It is possible that inherited differences in the pattern of induction by foreign chemicals of cytochrome P450 isoforms might similarly predispose to the development of PCT in humans.

Third, what is the relationship between group $\mathrm{A}$
PCT (families 1 to 4 ) and sporadic or type I PCT? Not all cases of type II PCT present with a family history of overt $\mathrm{PCT}^{711}$ (fig 3), and for overt PCT the degree of penetrance in group $A$ and group $B$ (type II PCT) families is similar (figs 1 and 3). It is therefore very likely that cases of PCT with the same of pathogenesis as those in group A occur sporadically. The number of such cases currently included in type I PCT remains to be determined and clearly has implications for understanding the pathogenesis of this type of PCT.

Now that cDNA probes for the human uroporphyrinogen decarboxylase gene are available ${ }^{20}$ restriction fragment length polymorphisms that are close to or within the gene are likely to be found in the near future. Their application to suitable families should help to distinguish between some of the possibilities outlined above.

We thank those physicians who have allowed us to study patients and families under their care. This work was supported by an MRC project grant to GHE and by grants from the Comision Asesora de Investigacion Cientifica y Tecnica and the Fondo de Investigaciones Sanitarias de la Seguridad Social.

\section{APPENDIX Statistical analyses}

Table 3 gives the mean and standard deviation of $\log \AA$ uroporphyrinogen decarboxylase concentration by $\overrightarrow{\vec{O}}$ family group, whether overtly affected, and in the 3 case of asymptomatic members of the type II PCT families, whether uroporphyrinogen decarboxylase concentration is greater or less than $75 \mathrm{ng} / \mathrm{mg}$. Though this distinction was made after collecting the data, examination of table 3 or fig 2 strongly suggests the explanation we have offered.

The purpose of significance testing is to determine how a priori unlikely a set of data is, based on a naive null hypothesis. We have applied several 윽 different statistical tests to the data, to determine $D$ whether the difference in pattern between group $\mathrm{A} O$ and group B families could credibly be due to the play of chance. In each case, a conservative option $\sigma$ involves grossing up the $p$ value to $1-(1-p)^{511}(511)$ being $2^{10-1}-1$ ) to take account of the a posteriori allocation of families to groups

Three types of analysis were carried out. Analysis (a) comes from a one way ANOVA of log uropor- $\frac{\bar{D}}{\mathscr{D}}$ phyrinogen decarboxylase concentration between $\stackrel{\rho}{+}$ families, extracting a $1 \mathrm{df}$ contrast between the two 0 groups of families. Analysis (b) involves fitting a mixture distribution to the probability density func- $\stackrel{\mathbb{D}}{\stackrel{D}{ }}$ tion of uroporphyrinogen decarboxylase concentra- $\mathbb{D}$ tion, conditional upon both family and phenotype; this was done both using a mixture of log-normal 
distributions and a binary distribution. Analysis (c) involves fitting binary distributions simultaneously to represent dichotomised uroporphyrinogen decarboxylase concentration and phenotype conditional on uroporphyrinogen decarboxylase concentration. For analyses (b) and (c) the effects of excluding probands were also examined.

In the continuous form of analysis (b), a model

$$
\mathrm{f}(\mathrm{y} \mid \text { family, phenotype })=p \phi\left(\frac{y-\mu_{1}}{\sigma}\right)+(1-p) \phi\left(\frac{y-\mu_{2}}{\sigma}\right)
$$

is fitted by constrained maximum likelihood. Here y denotes log uroporphyrinogen decarboxylase concentration and $\phi$ denotes the probability density function of the standard normal distribution. The likelihood is maximised with respect to $\mu_{1}, \mu_{2}$, and $\sigma$ (the means in the two components and the common standard deviation) jointly, using values of the mixing parameter $\mathrm{p}$ constrained as follows:

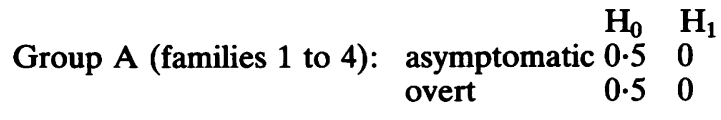

Group B (families 5 to 10): asymptomatic $0.5 \quad 0.5$ $\begin{array}{lll}\text { overt } & 0.5 \quad 1\end{array}$

Comparison of maximised likelihoods fitted using these two hypotheses gives a likelihood ratio test yielding $\chi^{2}$ on 2 or $3 \mathrm{df}$, the ambiguity of number of degrees of freedom arising from the fact that both models ignore phenotype for group A families, but this was not known to be appropriate before examining the data.

The discrete form of analysis (b) involves the model

$$
\operatorname{Pr}[\mathrm{U}=0 \mid \text { family, phenotype }]=\mathrm{p}
$$

where $U=0,1$ represent the lower and upper parts of the uroporphyrinogen decarboxylase distribution, dichotomised at $75 \mathrm{ng} / \mathrm{mg}$, and $\mathrm{p}$ is as above. In the spirit of non-parametric significance testing two subjects with uroporphyrinogen decarboxylase values of $75 \mathrm{ng} / \mathrm{mg}$ (one unaffected, family 2; one affected, family 8 ) are omitted.

In analysis (c), the model

$$
\begin{array}{ll}
\operatorname{Pr}[U=0]=p & \operatorname{Pr}[U=1]=1-p \\
\operatorname{Pr}[\text { affected } \mid U=0]=a & \operatorname{Pr}[\text { affected } \mid U=1]=b
\end{array}
$$

is fitted, estimating $\mathrm{p}, \mathrm{a}$, and $\mathrm{b}$ by unconstrained maximum likelihood: on $\mathrm{H}_{\mathrm{o}}$, using the same parameter values for all families; on $H_{1}$, allowing different values for the two groups of families. The ratio of the maximised likelihoods again yields a likelihood-ratio test.

Table 4 summarises all the analyses performed. Every $p$ value quoted is less than $1 / 9$. The only ones that do not reach significance at 0.05 all involve grossing up by 511 and also either ignore the information from unaffected subjects (a) or exclude probands and assume $3 \mathrm{df}(\mathrm{b}$ and $\mathrm{c})$. The conventional level of statistical significance is missed only when both an important part of the data is disregarded and an extraordinarily conservative approach to significance testing is made. We therefore conclude that there is strong evidence that the observed pattern represents heterogeneity between the two groups of families.

\section{References}

- 1 Harber LC, Bickers DR. Photosensitivity diseases: principles of diagnosis and treatment. Philadelphia: Saunders, 1981:189-223.

2 Waldenstrom J, Haeger-Aronsen B. Different patterns of human porphyria. Br Med $J$ 1963;ii:272-6.

${ }^{3}$ Waldenstrom J, Haeger-Aronsen B. The porphyrias: a genetic problem. In: Steinberg AG, Bearns AG, eds. Progress in medical genetics. Vol 5. New York: Grune and Stratton, 1967:58-101.

4 Kushner JP, Barbuto AJ, Lee GR. An inherited enzymatic defect in porphyria cutanea tarda: decreased uroporphyrinogen decarboxylase activity. J Clin Invest 1976;58:1089-97.

5 Elder GH, Urquhart AJ, De Salamanca R, Munoz JJ, Bonkovsky HL. Immunoreactive uroporphyrinogen decarboxylase in the liver in prophyria cutanea tarda. Lancet 1985;i:229-32.

6 Sweeney GD. Porphyria cutanea tarda, or the uroporphyrinogen decarboxylase deficiency diseases. Clin Biochem 1986;19:3-15.

${ }^{7}$ de Verneuil H, Aitken G, Nordmann Y. Familial and sporadic porphyria cutanea: two different diseases. Hum Genet 1978;44: 145-51.

8 Benedetto AV, Kushner JP, Taylor JS. Porphyria cutanea tarda in three generations of a single family. $N$ Engl J Med 1978;298: $358-62$.

9 de Verneuil H, Beaumont C, Deybach JC, Nordmann Y, Sfar $Z$, Kastally R. Enzymatic and immunological studies of uroporphyrinogen decarboxylase in familial porphyria cutanea tarda and hepatoerythropoietic porphyria. Am J Hum Genet 1984; 36:613-22.

10 Doss $M$, von Tiepermann R, Look D, et al. Hereditary and nonhereditary form of chronic hepatic porphyria: different behaviour of uroporphyrinogen decarboxylase in liver and erythrocytes. Klin Wochenschr 1980;58:1347-56.

"Elder GH, Sheppard DM, Enriquez de Salamanca R, Olmos A. Identification of two types of porphyria cutanea tarda by measurement of erythrocyte uroporphyrinogen decarboxylase. Clin Sci 1980;58:477-84.

12 Garcia Diez A, Enriquez de Salamanca R, Fernandez Hererra J, Olmos A, Aragues M, Rico Benavente R. Porphyria cutanea tarda in three brothers and one sister. Dermatologica 1981;162: 243-48.

13 Elder GH, Wyvill PC. Measurement of uroporphyrinogen decarboxylase using porphyrinogens prepared by chemical reduction. Enzyme 1982;28:186-93.

14 Enriquez de Salamanca R, Pena ML, Chinarro S, et al. Quantitative and qualitative porphyrin excretion in normal subjects. Int $J$ Biochem 1982;14:251-4.

15 Kushner JP, Edwards CQ, Dadone MM, Skolnick MH. Heterozygosity for HLA-linked hemochromatosis as a likely cause of 
the hepatic siderosis associated with sporadic porphyria cutanea tarda. Gastroenterology 1985;88:1232-8.

16 Mustajoki P. Normal erythrocyte uroporphyrinogen I synthase in a kindred with acute intermittent porphyria. Ann Intern Med 1981;95:162-6.

17 Grandchamp B, de Verneuil H, Beaumont C, Chretien S, Walter $\mathrm{O}$, Nordmann $Y$. Tissue-specific expression of porphobilogen deaminase: two isoenzymes from a single gene. Eur $J$ Biochem 1987;162:105-10.

18 Romeo PH, Raich N, Dubart A, Beaupain D, Mattei MG, Goossens M. Molecular cloning and tissue-specific expression analysis of human porphobilinogen deaminase and uroporphyrinogen decarboxylase. In: Nordmann Y, ed. Porphyrins and porphyrias. Montrouge: Colloque INSERM/John Libbey Eurotext Ltd, 1986:25-34.

19 de Verneuil H, Grandchamp B, Beaumont C, Picat C, Nord- mann Y. Uroporphyrinogen decarboxylase structural mutant $\left(\right.$ Gly $^{281} \rightarrow$ Glu) in a case of porphyria. Science 1986;234:732-4. ${ }^{20}$ Romeo PH, Raich N, Dubart A, et al. Molecular cloning and nucleotide sequence of a complete human uroporphyrinogen decarboxylase cDNA. J Biol Chem 1986;261:9825-31.

${ }^{21}$ Elder GH, Urquhart AJ. Human uroporphyrinogen decarboxylase. Do tissue-specific isoenzymes exist? Biochem Soc Trans 1984;12:661-2.

22 Kushner JP. The enzymatic defect in porphyria cutanea tarda. $N$ Engl J Med 1982;306:799-800.

Correspondence and requests for reprints to Professor G H Elder, Department of Medical Biochemistry, University of Wales College of Medicine, Heath Park, Cardiff CF4 4XN. 